\title{
English teachers' perception on teaching English vocabulary using songs as media for senior high school in Bandar Lampung
}

\author{
Refa Nisa Yolanda ${ }^{1}$, Ujang Suparman ${ }^{2}$, Fajar Riyantika ${ }^{3}$ \\ Universitas Lampung, Jl. Prof. Dr. Sumantri Brojonegoro, Rajabasa, Bandarlampung ${ }^{1,2,3}$ \\ ${ }^{I}$ Correspondence e-mail: yolandarefanisa@ymail.com
}

\begin{abstract}
The objective of this research is to find out teachers' perception on teaching English vocabulary using songs as media for Senior High School. This is a quantitative research.The sample of the research was 50 Senior High School English teachers in Bandar Lampung. The data were obtained from the close-ended questionnaire through Google form and were analyzed using SPSS.The result of this research showed that the teachers have positive perception on the use of songs to improve students' vocabulary especially in the effect of songs in learning vocabulary.
\end{abstract}

Keywords: teachers' perception, vocabulary, song.

\section{INTRODUCTION}

Vocabulary is considered as an important language component because it can support the learners' ability in developing language skills as quoted by Lado (1979) in Novi (2013). In line with Lado, Cameron (2001) emphasized the importance of vocabulary learning especially for children who learn a foreign language. She stated that vocabulary learning can serve as a stepping stone to learn and use grammar. Thus, it can be stated that vocabulary learning is also important to be conducted in the classroom because vocabulary can make the students convey their ideas both in oral and written form effectively.Therefore, English is the first foreign language being taught in Indonesia as a result the students in senior high school are expected to use English appropriately in communication. However, when people learn English as their foreign language, they must master the vocabulary first because low vocabulary mastery also can make them unable to express their ideas in English. Thus, learners need to be highly concentrated in memorizing vocabularies (Thornbury,2002).

Based on the previous research done by Thornbury (2002), it was found that there are difficulties in teaching vocabulary in the class. The students have problems in memorizing and understanding vocabulary. They easily forgot some new words that the teacher taught and sometimes they could not remember how to pronounce it. Language teachers should consider how to manage an interesting classroom activity so that the learners can gain great success in their vocabulary learning. Song is one of the English media that teachers can use in teaching vocabulary. As stated by Alipour et al (2012), they found out that the use of songs that is familiar with the students in the classroom makes them more interested and focus to learn. Also, Medina (2002) states while the learners relax, they are also more attentive than usual, and therefore, more receptive to learning. 
One essential consideration in making the most effective use of songs as media is the teacher's perception. According to Lewis (2001), he states that perception refers to a process of information collecting about the world by means of the senses. A teacher's perception is one essential consideration. It is because a teacher is an important component who operates an extensive role in vocabulary tuition (Harmon 2009). Regarding the statement above, it can be said that the teacher has a big role in learning vocabulary mastery for the students. Hence, Harmon (2009) states that teachers should focus on applying strategy, technique, or method in the English teaching process.

So in this research, the researcher would like to find out perception from the teachers on using English songs to improve students' vocabulary mastery. Although the previous researchers have already conducted research related to perceptions such as teachers' perceptions of English language teaching media and teachers' perceptions towards teaching writing using word games but none of them talked about teachers' perception on the use of English songs which focused on students' vocabulary mastery.

\section{METHODS}

This research used quantitative data approach using questionnaire to investigate the teachers' perception on teaching English vocabulary by using songs (Lodico, et.al.2006). The population of the research was the 132 English teachers who worked in senior high school in Bandar Lampung and the sample was 50 English teachers who filled the questionnaire in Google form. The data were taken based on close-ended questionnaire. Therefore, the statistical data from teachers' perception was analyzed through SPSS based on the scale of teachers' statements ranging from 1-4 (Strongly Agree, Agree, Disagree, Strongly Disagree).

\section{RESULTSAND DISCUSSIONS}

\section{Results}

The researcher gathered the result from the questionnaire. The results obtained from the analysis of data for each item will be given in three tables based on aspects of perception as follow:

Table 1 Perception to the use of songs

\begin{tabular}{|c|c|c|c|c|c|c|c|c|}
\hline \multirow{3}{*}{ Statement } & \multicolumn{8}{|c|}{ Option } \\
\hline & \multicolumn{2}{|c|}{$\begin{array}{l}\text { Strongly } \\
\text { Disagree }\end{array}$} & \multicolumn{2}{|c|}{ Disagree } & \multicolumn{2}{|c|}{ Agree } & \multicolumn{2}{|c|}{$\begin{array}{c}\text { Strongly } \\
\text { Agree }\end{array}$} \\
\hline & $\mathbf{N}$ & $\%$ & $\mathbf{N}$ & $\%$ & $\mathbf{N}$ & $\%$ & $\mathbf{n}$ & $\%$ \\
\hline $\begin{array}{l}\text { 1- I believe that songs should be an } \\
\text { essential part of English teaching } \\
\text { curriculum to improve students' } \\
\text { vocabulary }\end{array}$ & 5 & $10 \%$ & 8 & $16 \%$ & 14 & $28 \%$ & 23 & $46 \%$ \\
\hline $\begin{array}{l}\text { 2- I believe that I do not have enough } \\
\text { other resources to use as songs to } \\
\text { improve students' vocabulary mastery. }\end{array}$ & 10 & $20 \%$ & 18 & $36 \%$ & 14 & $28 \%$ & 8 & $16 \%$ \\
\hline $\begin{array}{l}\text { 6- I believe that songs provide appropriate } \\
\text { proportion or repetition that helps my } \\
\text { students to retain vocabulary }\end{array}$ & 5 & $10 \%$ & 7 & $14 \%$ & 16 & $32 \%$ & 22 & $44 \%$ \\
\hline
\end{tabular}


table 1 demonstrate parallel findings to earlier research studies related to the teachers' perception in the use of songs to improve students' vocabulary contexts. Most of the teachers believe that songs should be an essential part of English teaching curriculum to improve vocabulary and provide appropriate proportion or repetition that helps students to retain vocabulary. It is also highly motivating and important to develop vocabulary mastery. Moreover, the teachers believe that there are many other resources to use other than songsin improving students' vocabulary.

Table 2 Perception to the effect of songs

\begin{tabular}{|c|c|c|c|c|c|c|c|c|}
\hline \multirow{3}{*}{ Statement } & \multicolumn{8}{|c|}{ Option } \\
\hline & \multicolumn{2}{|c|}{$\begin{array}{l}\text { Strongly } \\
\text { Disagree }\end{array}$} & \multicolumn{2}{|c|}{ Disagree } & \multicolumn{2}{|c|}{ Agree } & \multicolumn{2}{|c|}{$\begin{array}{c}\text { Strongly } \\
\text { Agree }\end{array}$} \\
\hline & $\mathbf{N}$ & $\%$ & $\mathbf{N}$ & $\%$ & $\mathbf{n}$ & $\%$ & $\mathbf{n}$ & $\%$ \\
\hline $\begin{array}{l}\text { 3- I believe that songs accelerate the } \\
\text { process of memorizing vocabulary. }\end{array}$ & 4 & $8 \%$ & 10 & $20 \%$ & 14 & $28 \%$ & 22 & $44 \%$ \\
\hline $\begin{array}{l}\text { 4- I believe that songs present many } \\
\text { opportunities for senior high school } \\
\text { students to show their skills in } \\
\text { vocabulary. }\end{array}$ & 5 & $10 \%$ & 8 & $16 \%$ & 22 & $44 \%$ & 15 & $30 \%$ \\
\hline $\begin{array}{l}\text { 16- I believe that using songs can lower } \\
\text { students' anxiety toward learning } \\
\text { English. }\end{array}$ & 1 & $2 \%$ & 9 & $18 \%$ & 24 & $48 \%$ & 16 & $32 \%$ \\
\hline
\end{tabular}

As can be seen in table 2, most of the teachers believe that using songs can lower students' anxiety and accelerate the process of memorizing vocabulary. In brief, it is possible to argue that the teachers have positive perception toward the effect of songs to improve students' vocabulary mastery.

Table 3 Perception to the application of songs

\begin{tabular}{|c|c|c|c|c|c|c|c|c|}
\hline \multirow{3}{*}{ Statement } & \multicolumn{8}{|c|}{ Option } \\
\hline & \multicolumn{2}{|c|}{$\begin{array}{l}\text { Strongly } \\
\text { Disagree }\end{array}$} & \multicolumn{2}{|c|}{ Disagree } & \multicolumn{2}{|c|}{ Agree } & \multicolumn{2}{|c|}{$\begin{array}{c}\text { Strongly } \\
\text { Agree }\end{array}$} \\
\hline & $\mathbf{n}$ & $\%$ & $\mathbf{N}$ & $\%$ & $\mathbf{n}$ & $\%$ & $\mathbf{n}$ & $\%$ \\
\hline $\begin{array}{l}\text { 5- I find it difficult to find an } \\
\text { appropriate song to teach } \\
\text { vocabulary. }\end{array}$ & 9 & $18 \%$ & 21 & $42 \%$ & 13 & $26 \%$ & 7 & $14 \%$ \\
\hline $\begin{array}{l}\text { 8- I believe that using songs to teach } \\
\text { vocabulary may distract students' } \\
\text { attention during the lesson. }\end{array}$ & 7 & $14 \%$ & 7 & $14 \%$ & 23 & $46 \%$ & 13 & $26 \%$ \\
\hline $\begin{array}{l}\text { 10- I can easily access and find } \\
\text { appropriate songs to use in my } \\
\text { English class to teach vocabulary. }\end{array}$ & 5 & $10 \%$ & 12 & $24 \%$ & 17 & $34 \%$ & 16 & $32 \%$ \\
\hline $\begin{array}{l}\text { 13- I believe that songs are not very } \\
\text { effective in teaching vocabulary to } \\
\text { senior high school students }\end{array}$ & 17 & $34 \%$ & 18 & $36 \%$ & 12 & $24 \%$ & 3 & $6 \%$ \\
\hline
\end{tabular}




\begin{tabular}{lllllllll}
\hline 15- $\begin{array}{l}\text { I believe that I cannot measure } \\
\text { students' vocabulary mastery } \\
\text { when I use songs in my classes. }\end{array}$ & 5 & $10 \%$ & 29 & $58 \%$ & 14 & $28 \%$ & 2 & $4 \%$ \\
\hline $\begin{array}{l}17- \\
\begin{array}{l}\text { I use songs in my classes as } \\
\text { often as possible }\end{array}\end{array}$ & 6 & $12 \%$ & 18 & $36 \%$ & 21 & $42 \%$ & 5 & $10 \%$ \\
\hline
\end{tabular}

It can be clearly seen in table 3, teachers' perception towards the application of songs to improve students' vocabulary mastery was explored by means of six statements and the result showed that the teachers also have positive perception in the aspect of the application of songs.

The resultof teachers' perception on the use of songs to improve students' vocabulary mastery of each aspect of the questionnaire will be described bellows:

Table 4 Percentage of perception

\begin{tabular}{|lc|}
\hline \multicolumn{1}{|c|}{ Aspects } & Percentage \\
\hline Perception to the use of songs to improve vocabulary & $69.7 \%$ \\
\hline Perception to the effect of songs to improve vocabulary & $76 \%$ \\
\hline $\begin{array}{l}\text { Perception to the application of songs to improve } \\
\text { vocabulary }\end{array}$ & $66.3 \%$ \\
\hline
\end{tabular}

\section{Discussions}

The research question of this research is to investigate the teachers' perception on teaching English vocabulary by using songs. The statements related to perception in the questionnaire concern with three aspects of perception from Vernon (1987) which were what they are (the use of songs), what they do (the effect of songs), and what they can do with it (the application of songs). In addition to that, the researcher put question whether the teachers had used songs in their class or not to make sure that the test was valid.The researcher did pre-observation at one of SMA in Bandar Lampung and the result showed that the teachers at SMAN 7 Bandar Lampung had used songs as a media for their teaching-learning process.

Furthermore, in this research it was found out that teachers have positive perception on teaching English vocabulary by using songs. According to Irwanto (2002), he stated that positive perception is perception that describes all information and respond object that perceived positively. Furthermore, among the three aspects of perception, teachers' perception towards the effect of songs is one of the aspect which has the most percentage. It is in line with Illinawati (2018) the result on its research stated that the effect of songs to students' vocabulary mastery are the Students' memorization improve in finding the meaning and also improve students' knowledge in identifying the words based on their cluster. Furthermore, on this aspect most of the teachers agreed with statement 16 which says "I believe that using songs can lower students' anxiety toward learning English". This is in line with Shen (2009) who claimed that using English songs in EFL classrooms can successfully bring about affective learning through providing a harmonious classroom atmosphere, reduce students' anxiety, foster their interests, and motivate them to learn the target language, as Suparman (2010) stated that motivation is perhaps the most frequently used term to explain the success or failure of language. This is also 
supported by Shahi (2016) who found out that e-learning with multimedia teaching methods can reduce students' anxiety and stress levels. It enables students to enjoy and interact during learning.

The teachers also believe that teaching English vocabulary by using songs not only reduces students' anxiety but also accelerates the process of memorizing vocabulary and present many opportunities for senior high school students to show their skills in vocabulary. Moreover, most of the teachers believe that songs provide an appropriate proportion or repetition that helps students' retain vocabulary, and songs plays important role in developing vocabulary mastery in senior high school students. However, some of the teachers think that using songs in their class can be time consuming.

The aspect of perception which received the highest percentage is the aspect of the use of songs. According to statement 9, the teachers believe that songs are a highly motivating and entertaining way of teaching vocabulary in senior high school. It is in line with Alipour et al (2012) which claimed that the learners' attendance in the class was noticeable and the learners seemed more motivated in learning vocabulary items through song. Also according to statement 11 , the teachers disagree if the use of songs is only for fun, and breaking down boredom as though with statement 1 which the teachers believe that songs should be an essential part of the English teaching curriculum. Otherwise, according to statement 7, only $28 \%$ of teachers believe that songs are fun and full of pedagogical value while Millington (2011) in its journal stated that songs have many reasons to be considered as a valuable pedagogical value. Furthermore, Sevik (2011) found that Turkish EFL teachers have strong beliefs about the pedagogical value of songs

Meanwhile, according to statement 5,60\% of the teachers believe that it is not difficult to find an appropriate song to teach vocabulary but the rest think that it is quite difficult to find an appropriate song to teach vocabulary. It means that finding a song to teach vocabulary is not difficult but not that easy though. This is supported by Millington (2011) who said that the teacher needs to be careful in selecting a suitable song for his or her class. The language, vocabulary, and sentence structure of some songs can be quite different from those used in spoken English. And also to maintain variety in the classroom, the teacher needs a good playlist of songs. Therefore, depending on the strong beliefs of teachers about the effect and the use of songs, it is believed that songs should be approached on a structured and systematical basis to help the teachers find appropriate songs to teach vocabulary.

With regards to the dilemma, mentioned for the findings from statement 8 , the teachers believe that using songs to teach vocabulary may distract students' attention during the lesson. On the other hand the teachers believe that the effect of using songs can lower students' anxiety toward learning English and also accelerate the process of memorizing vocabulary.

Finally, this research is far from perfection therefore there are some weaknesses on this reseach. Such as, its limitation in conducting survey only for Senior High School teachers. Meanwhile, students' perception might also be essential. And also the researcher can not observe all the teachers in this research due to the limitation of time and pandemic of Covid 19. 


\section{CONCLUSIONS AND SUGGESTIONS}

\section{Conclusion}

In line with the discussion of the research findings in the previous chapter, the researcher comes to the conclusion that the teachers have positive perception towards songs because on the use of it, the teachers believe songs provide appropriate proportion or repetition that helps the students retain vocabulary. Furthermore, the teachers believe that the effect of the implementation of songs can lower students' anxiety. On the contrary, in the application of songs the teachers believe that it is not that easy to find an appropriate song to teach vocabulary.

\section{Suggestions}

In reference to the conclusion above, some suggestionso the English teacher and further researcher are proposed as follows. First, the researcher suggests that in finding an appropriate song to teach vocabulary in senior high school students, teachers have to pay attention of several important rules, which are: The teacher cannot choose the songs they like, because the songs chosen by the teacher will influence the students' learning. Songs should be relevant with the students' characteristics. It means that the teachers have to choose songs that is related to their social live. The songs' lyrics should contain only appropriate words. The vocabulary contains in songs should be at the level of the students. The message of the songs should be useful for the students. Songs should be interesting, dynamic, and cheerful in rhythm so that the songs could attract students' attention. Second, The reseracher suggests the teacher to implement songs for writing, reading, listening and also speaking skill. Third, This study was conducted at the senior high school level in the field of teaching English vocabulary using songs. Therefore, further researchers can try to find out the students' perceptions using other media in different levels of school: junior high school and university level. Fourth, Due to the covid-19 pandemic, the collecting of the data could only use an online questionnaire. Therefore, further researchers may use other survey instruments such as interview and observation to get more accurate result of the data.

\section{REFERENCES}

Alipour, M and Gorjian, B \& Zafari, I. (2012). The effects of songs on EFL learners' vocabulary recall and retention:The case of gender. World Science Publisher Vol 1 No.3 2012 pp.140143 Retrieved September 2019 http://citeseerx.ist.psu.edu/viewdoc/download?doi=10.1.1.8 $71.7094 \&$ rep=rep $1 \&$ type $=$ pdf

Cameron, L. (2001). Teaching languages to young learner. Cambridge: Cambridge University Press.

Harmon, J. M., Wood, K. D. \& Keser, K. (2009) Promoting vocabulary learning with Interactive word wall. Middle School Journal, 40(3)2009, 58-63. https://www.researchgate.net/publication/241667999_Promoting_Vocabulary_Learning_wi th_the_Interactive_Word_Wall

Illinawati., Darma, Y.P. (2018). Improving students' vocabulary through songs. Journal of English Educational Study, Volume 1 Issue 2, Page 66-70. E-ISSN 2655-0776

Irwanto. (2002). Psikologi umum. PT. Prenhallindo. Jakarta. 
Lado, R. (1979). Language teaching: A scientific spproach. New York: Mc, Graw- Hill inc.

Lewis, A. (2001). The issue of perception: Some educational implications. Educare, 272-288. Retrieved from www.andrewlewis.co.za/Lewis.Perception.Educare1_v30_n1_a15.pdf

Lodico, M. G., Spaulding, D. T., \& Voegtle, K. H. (2006). Method in educational research. San Fransisco: Jossey-Bass.

Medina, S. L. (1990). The effects of music upon second language vocabulary acquisition (Eric). ESL through Music.N/A. https://eric.ed.gov/?id=ED352 834

Millington, N. T (2011). Using songs effectively to teach English to young learners: teaching practice. Language Education in Asia, Volume2, Issue 1.http://www.leia.org/LEiA/LEiA\%20VOLUMES/Download/LEiA_V2_I1_2011/LEiA_V2I1 A11_Millington.pdf

Sevik, M. (2011). Teacher views about using songs in teaching English to young learners. Educational Research and Reviews.DOI: 10.5897/ERR11.250

Shahi, M.A. (2016). The impact of e-learning on improving Iranian learners' language skills: Decreasing learning anxiety. Journal of Fundamental and Applied Science, ISSN 112 9867.

Shen, C. (2009). Using English songs: an enjoyable and effective approach to ELT. CCSE English Language Teaching Journal,2009 88-94 https:/lfiles .eric.ed.gov/fulltext/EJ1082242.pdf

Thornbury, S. (2002). How to teach vocabulary. London: Longman.

Suparman, U. (2010). Psycholinguistics: The theory of language acquisition. Bandung: Arfino Raya

Vernon, M. D. (1987). The psychology of perception. Middlesex: Penguin Books. 